\title{
Practice and Procedure Before Administrative Tribunals
}

W ITH the growth in the number and authority of administrative tribunals, their practice and procedure have become of increasing interest and importance to the profession.

The Interstate Commerce Commission, the Federal Trade Commission, the Federal Power Commission, the Bureau of Internal Revenue, the Land Office, the various federal departments, the state public utility and raidroad commissions, industrial accident commissions, water commissions, corporation commissions, licensing boards for doctors, dentists, lawyers, peddlers, engineers, barbers and realtors, also superintendents of banks, racing commissions, insurance commissions, and state and local boards of health, are illustrative of the scope and variety of national, state and local administrative agencies.

It will be the purpose of this paper to give consideration to the subject of practice and procedure before administrative tribunals in general, from the time of the acquisition of jurisdiction to the making of the order.

Attention will be invited to the underlying philosophy of administrative practice and procedure rather than to the operation of any particular tribunal or tribunals.

\section{Varying Functions of Administrative Agencies}

"Administrative law," recently said Judge Cuthbert W. Pound of the Court of Appeals of New York, "implies that branch of modern law under which the executive department of government, acting in a quasi-legislative or quasi-judicial capacity, interferes with the conduct of the individual for the purpose of promoting the well-being of the community."

The use of the word "quasi" will be noted. Maitland once said that "quasi" is one of the few latin words which english lawyers really love. Whenever it is difficult to reconcile the functions of an agency of government with established constitutional principles, Sir Knight "Quasi" rushes to the rescue and saves the day.

In speaking of administrative law, we have in mind, as Judge Pound said, the performance of functions by the executive department of the government. Those functions, however, may run the 
entire gamut of governmental power - executive, legislative and judicial.

The same administrative tribunal may, at different times, exercise each of these functions, with various shadings off, the one into the other.

It is important to note that the practice and procedure of an administrative agency vary with the nature of the function which it is exercising in the particular matter before it.

The function may be purely executive-enforcement of the law. We are not here particularly concerned with that function.

It may be purely legislative. Thus, when the Interstate Commerce Commission prescribes the forms of accounts to be kept by carriers, or when a state public utility or industrial accident commission prescribes the character of construction of public utility or industrial property to promote the safety of the public or of the employees, the tribunal is enacting a rule or regulation of general application. It is exercising a purely legislative function. Unless the legislature otherwise provides, no hearing is necessary in connection with the exercise of a legislative function. When Congress or a state legislature enacts a law, hearings by committees are sometimes held for the purpose of securing information, but it is, of course, well known that no hearing is necessary as a condition precedent to the enactment of a statute. The same situation applies to administrative agencies exercising legislative functions, unless the statute, as to that particular case, has provided for a hearing.

Again, the function under consideration may be a so-called quasilegislative function. A familiar illustration is the establishment of a rate to be charged by a common carrier or a public utility. A rate operates in the future. Its establishment is a legislative act. At the same time, its determination is the result of a controversy between one or more specific carriers or utilities and their customers, and the method of procedure is analogous to that of the courts. In the exercise of quasi-legislative functions, a hearing in some form or other is, with rare exceptions, always provided by statute.

Further, the function under consideration may be purely judicial, i. e., the decision of an existing controversy between specific parties, without the establishment of a rule or regulation for the future. Judicial functions are exercised when, for instance, the Interstate Commerce Commission awards reparation in connection with an overcharge, or when a state industrial accident commission awards a specific sum of money to be paid by an employer to an injured employee. A less familiar but very interesting illustration is found 
in the statutory provisions in California under which on application of either the public authority or the public utility the State Railroad Commission may fix and determine the compensation to be paid by the public authority for the property of the public utility to be thereafter acquired by means of eminent domain proceedings. ${ }^{2}$ The findings of the Commission fixing the just compensation are by law made final and can not be changed by any court. In subsequent eminent domain proceedings in the courts, the compensation thus determined by the Commission is conclusive. ${ }^{2}$ Where the function is thus judicial, the practice and procedure may naturally be expected to follow very closely those of the courts. It would be a mistake, however, to make any generalization on this subject, as is shown by the fact that where the statute so provides, an administrative tribunal may be specifically exempted, in the performance of its judicial functions, from either the common law rules or the statutory rules of evidence.

Finally, the function under consideration may be neither executive, nor purely legislative, nor quasi-legislative, nor purely judicial. It may be quasi-judicial, that is, resembling a judicial function and yet differing from it in varying respects and degrees.

Without multiplying illustrations, it will be clear that generalization with reference to the practice and procedure before administrative agencies is impossible.

What the practitioner must do, in each instance, is to ascertain and follow with great care the statutory provisions which are applicable to the particular class or type of case before the particular administrative agency. It is only in the absence of such statutory provision that he is permitted and obligated to apply general principles. These general principles will depend in each instance on the nature of the function which is being exercised.

\section{Conflict of Opposing Forces and Tendencies}

Before addressing ourselves to a few specific aspects of administrative practice and procedure, it may be helpful to give brief con-

1 Public Utilities Act, Sec. $47 \mathrm{~b}$, (Cal. Stats. 1913, c. 339, pp. 683-4, as amended by Cal. Stats. 1915, c. 91, pp. 115, 139, and by Cal. Stats. 1917, c. 1.76, p. 261).

2 Marin Water and Power Company v. Railroad Commission (1916) 171 Cal. 706, 711-13, 154 Pac. 864, Ann. Cas. 1917c, 114; Marin Municipal Water District v. Marin Water and Power Company (1918) 178 Cal. 308, 314, 173 Pac. 469 ; Marin Municipal Water District v. North Coast Water Company (1918). 178 Cal. 324, 173 Pac. 473. See also East Bay Municipal Utility District v. Railroad Commission (1924) 194 Cal. 603, 229 Pac. 949. 
sideration to the play of conflicting forces, resulting from more or less conflicting habits of mind and desires, which are largely responsible for the great variations in statutory provisions on the subject of administrative practice and procedure. A consideration of these conflicting forces will explain much which otherwise would be confusing.

On the other hand, we have the desire for speed and efficiency, for simplicity and the reduction of expense in the administration of governmental functions.

Lord Shaw of Dunfermline said in the famous case of Local Government Board v. Arlidge, ${ }^{3}$ decided by the House of Lords in 1914:

"Judicial methods may, in many points of administration, be entirely unsuitable, and produce delays, expense and public and private injury. . . . If administration is to be effective, it must be the master of its own procedure."

Again, on the one hand, we have the tendency to break away from the political and constitutional theories of 1776 and 1789 , with their separation of the powers of government, and to seek newer methods of government which shall more adequately fit modern needs.

On the other hand, we have the natural reaction of the AngloSaxon temperament against interference with liberty by administrative processes, which has led in the United States to the dominance of the judiciary over the other two departments of the government.

The play of these conflicting forces, the one now dominating, now the other, is largely responsible not merely for the varying power and authority conferred upon the different administrative agencies, but also for their practice and procedure and the decisions of the courts in connection therewith.

Administrative practice and procedure are still in the making. Changes of great importance will take place in the next few years. These changes will be all the more interesting and significant to those who understand and appreciate the play of underlying habits of thought and training and desires which will be responsible for the developing practice and procedure.

Some comments and suggestions will now be made very briefly on the following subjects in connection with administrative procedure:

Acquisition of jurisdiction to act;

Rules of procedure, including pleadings;

Notice and hearing; and

Evidence.

3 [1915] A. C. 120. 


\section{ACQUISITION OF JURISDICTION to ACT}

The statute always specifies the acts by means of which the administrative agency acquires jurisdiction to act.

If the function is legislative, then, unless a hearing is specifically provided, the statute itself confers the jurisdiction and the administrative agency may proceed, without the filing of pleadings or a hearing, to the exercise of the authority conferred.

On the other hand, if the function is judicial or quasi-judicial or quasi-legislative and in certain cases also where it is purely legislative, the statute provides for the acquisition of jurisdiction by the filing of pleadings, called complaints or petitions, as the case may be. Complaints may generally be filed by interested members.of the public or associations or organizations, with the qualification that it is sometimes provided that no complaint shall be entertained by a public service commission, except upon its own motion, as to reasonableness of public utility rates unless the same is filed by a public authority or by a designated number of consumers. In California, the number is twenty-five.

One very significant difference between the procedure before the courts and that before administrative agencies is that it is frequently provided that the administrative agency may on its own motion institute an investigation or proceeding by the filing of an appropriate pleading. The reason for this procedure is that there rests on such administrative agencies a measure of responsibility for the administration of the law and the effectuation of the governmental policies to which the law gives expression.

\section{Rules of Procedure, including Pleadings}

The statute frequently confers upon the administrative agency the power to adopt its own rules of practice and procedure. These rules generally provide for simple forms of pleadings and prescribe a procedure designed to be as simple, direct and effective as possible.

Some of these tribunals have had some interesting and amusing experiences in connection with the adoption of their rules of practice and procedure. I remember very well the case of a far western state railroad commission. The commission's attorney had drafted rules of procedure which eliminated all demurrers, motions to strike and other dilatory processes. Copies of the draft were sent out to the attorneys for all the important public utilities as well as city attorneys,

4 Public Utilities Act, Sec. 60, (Cal. Stats. 1915, c. 91, pp. 115, 157). 
for their suggestions and criticisms. A day was set for a hearing on the proposed rules before they should be adopted by the commission. The public utility attorneys appeared en masse and protested vigorously that the rights of their clients under the Federal Constitution were being ruthlessly violated. Finally, a prominent member of the San Francisco Bar, a Scotchman noted for his epigrams, ${ }^{5}$ rose and said that all that lawyers do nowadays is four things: "First, do nothing; second, try to prevent the other fellow from doing anything; third, secure continuances; and fourth, collect their fees." The next day the San Francisco papers published interviews with large numbers of leading lawyers and judges, many of whom vigorously protested against the proposed deprivation of the alleged "constitutional rights" to inefficiency and delay. Notwithstanding the storm, the rules were adopted by the commission. Long since, the lawyers who had complained of them became their most ardent champions.

In this connection, it is interesting to observe that the legislatures of the various states, while retaining tenacious control of the practice and procedure of the state courts, very greatly to the disadvantage of that practice and procedure, have been quite ready to grant to administrative tribunals such as railroad commissions and industrial accident commissions, the right to adopt their own rules of practice and procedure. This is continually being done, notwithstanding the bold disregard by these administrative tribunals of the old court rules of practice and procedure which were inherited from England at a time when the practice and procedure of the courts in that country were in their most unsatisfactory condition. It may well be suggested that the public and their representatives might well take a leaf from the book of experience of these administrative tribunals and finally confer upon the courts the power to prepare their own rules of practice and procedure.

\section{Notice AND HEARING}

Except in certain instances where the function is legislative, the statute generally provides that the administrative tribunal can act only after notice and hearing.

In all such cases, compliance must, of course, be had with the due process of law provisions of the fifth and the fourteenth amendments to the Federal Constitution. There must be opportunity to be present during the taking of the testimony, to know the nature

The late Gavin McNab of San Francisco. 
and contents of all testimony, and to present all relevant evidence and contentions, i. e., the party must have "his day in court."

However, as we shall see, this does not mean that a party can avail himself of all the common law or statutory rules of evidence. Due process does not go so far.

In connection with notice and hearing, the most interesting situation arises in a case in which a statute confers upon an administrative tribunal judicial or quasi-judicial jurisdiction but does not lay down any rule as to notice and hearing or as to how the jurisdiction shall be exercised.

There have been few, if any, cases of that character in the United States for the reason, probably, that our legislatures practically always provide for hearings if the administrative tribunal is to act judicially or quasi-judicially.

In England, the question was decided in 1914 by the House of Iords in the famous case of Local Government Board v. Arlidge, supra. A borough council was given authority to close dwelling houses which it found to be unfit for habitation. An appeal lay to the Local Government Board, an administrative tribunal. This Board, as provided by law, sent out an inspector to look at the premises and hold a public hearing. He then submitted a confidential report to the Local Government Board which, without further hearing, decided the appeal. The house-owner in this case contended that he was entitled (a) to see the inspector's report and (b) to be heard by the very officers who decided his case, i.e., the members of the Local Government Board. He urged that failure to let him see the report or to be thus heard was "contrary to natural justice"there being no fifth or fourteenth amendment in England.

The House of Lords unanimously decided against him. Haldane, Lord Chancellor, held that:

"In the absence of directions in the statute to the contrary-

the results of the inquiry must be reached by the administrative tribunal's ordinary procedure"

even though such procedure did not provide for a hearing by the Board. He added that the Board was not bound to hear the houseowner orally.

Lord Shaw addressed himself particularly to the claim that natural justice required an inspection of the report and the opportunity to be heard by the tribunal which decided the appeal. He said:

"The words 'natural justice' occur in arguments and sometimes in judicial pronouncements in such cases. My Lords, when a central administrative board deals with an appeal from 
a local authority, it must do its best to act justly and to reach just ends by just means. If the statute prescribes the means, it must employ them. If it is left without express guidance, it must still act honestly and by honest means. In regard to these, certain ways and methods of judicial procedure may very likely be imitated; and lawyer-like methods may find special favour from lawyers. But that the judiciary should presume to impose its own methods on administrative or executive officers is a usurpation. And the assumption that the methods of natural justice are ex necessitate those of courts of justice is wholly unfounded. This is expressly applicable to steps of procedure or forms of pleading."

Lord Moulton added:

"It is said truthfully that on such an appeal the Local Government Board must act judicially, but this, in my opinion, only means that it preserves a judicial temper and performs its duties conscientiously, with a proper feeling of responsibility, in view of the fact that its acts affect the property and rights of individuals."

It will be interesting to note whether the far-reaching decision in the Arlidge case will have any effect on legislation and administrative procedure in this country.

\section{EVIDENCE}

Here, again, we must look to the nature of the function to be performed and, as always, to the statute.

If the function is legislative, then, even though the statute requires a hearing, the courts will permit a wide latitude to the administrative tribunal in the evidence, or means of administrative proof, which it admits or rejects or requires. A good illustration of this principle is the Assigned Car Case ${ }^{8}$, decided by the Supreme Court of the United States on May 31, 1927. In this case, the Supreme Court upheld an order of the Interstate Commerce Commission establishing a rule or regulation for the distribution of coal cars. The court held that in promulgating such rule it is not necessary for the Commission to have before it evidence as to the situation of each railroad to be affected but the Commission, just like a legislature, may reason from the particular to the general.

On the other hand, if an administrative tribunal is exercising a purely judicial function it will be very careful, in the absence of some statutory provision to the contrary, to follow the rules of evidence as they are applied in the courts.

8 United States v. Berwind-White Coal Mining Company (1926) 9 F. (2d) 429 ; aff. (1927) - U. S. -, 71 L. Ed. 780. 
As to the great mass of quasi-legislative and quasi-judicial functions of admimistrative agencies deciding after notice and hearing, the following principles, which were announced by the Supreme Court of the United States in its most recent decision referring to the Interstate Commerce Commission may, in general, be said to be applicable: (Assigned Car Case, supra):

"It is not for the courts to weigh the evidence introduced before the Commission . . . or to enquire into the soundness of the reasoning by which its conclusions are reached ... or to question the wisdom of regulations which it prescribes. These are matters left by Congress to the administrative 'tribunal appointed by law and informed by experience'." "

Now, just a word as to one or two well-known rules of evidence.

The "best evidence" rule generally does not apply before administrative agencies. They constantly admit tabulations and summaries of book entries without calling for the books or the particular persons who made the entries.

Whether the "hearsay" rule applies, depends upon the language of the statute applicable to the particular tribunal. On the subject of evidence and procedure before industrial accident commissions alone, there are at least four general forms of statutes in the United States. ${ }^{8}$ The California Workmen's Compensation Law originally provided that the Industrial Accident Commission should not be bound by the "technical rules of evidence". The Supreme Court of California thereupon decided that the Commission was bound by the hearsay rule, for the reason that this rule was not a "technical" but a "substantial" rule of evidence." The California Legislature there-

7 Illinois Central Railroad Company v. Interstate Commerce Commission (1907) 206 U. S. 441, 454. 27 Sup. Ct. Rep. 700; Interstate Commerce Commission v. Ill. Central Railroad Company (1910) 215 U. S. 452, 471, 30 Sup. Ct. Rep. 155; Skinner \& Eddy Corporation v. United States (1919) 249 U. S. 557, 562, 39 Sup. Ct. Rep. 375; United States v. New River Company (1924) 265 U. S. 533, 542, 44 Sup. Ct. Rep. 610; Northern Pacific Railway Company v. Department of Public Works of Washington (1925) 268 U. S. 39, 44, 45 Sup. Ct. Rep. 412; Western Paper Makers' Chemical Company v. United States (1926) 271 U. S. 268, 271, 46 Sup. Ct. Rep. 500; Chicago Rock Island \& Pacific Railway Co. v. United States (1927) - U. S. - 71 L. Ed 592, 594; Oro Electric Corporation v. Railroad Commission (1915) 169 Cal. 466, 147 Pac. 118; Brewer v. Railroad Commission (1922) 190 Cal. 60, 77-8, 210 Pac. 511; Williamson v. Railroad Commission (1924) 193 Cal. 22, 35, 222 Pac. 803.

${ }^{8}$ Frank A. Ross, "The applicability of common law rules of evidence in proceedings before Workmen's Compensation Commissions," 36 Harvard L. Rev. 263, 274 (1923).

9 Workmen's Compensation, Insurance and Safety Act of California, Cal. Stats. 1913 , c. $176, \$ 77$, pp. $279,313$.

10 Englebretson v. Industrial Accident Commission (1915) 170 Cal. 793, 799, 151 Pac. 421. 
upon amended the law so as to provide that the Commission shall not be bound by the "common law or statutory rules of evidence"..1

In one matter, the courts, state and federal, are unanimous. A decision resting on matter which is not part of the record, is void. Such decision violates the due process clause of the fifth and the fourteenth Amendments. The Supreme Court has several times so decided with reference to decisions of the Interstate Commerce Commission and the state courts have many times so decided with reference to decisions of state administrative agencies in those cases in which a hearing was necessary. ${ }^{12}$

This situation, however, presents a very interesting query as to the extent to which the doctrine of judicial notice, or, as it might more appropriately be called, administrative notice,--would permit the members of the administrative tribunal to avail themselves of facts not made a part of the formal record. The highest courts of New York and California have held that the doctrine of judicial notice applies to administrative tribunals as well as to courts. ${ }^{13}$ Thus far, we have already gone. Of what documents on file with it and of what facts may an administrative tribunal take judicial or administrative notice, and by incorporation in the decision make the same part of the record on review? As far as administrative law is concerned, this field is thus far almost untouched.

The question who may introduce the evidence is of interest. Before a court, generally only the parties litigant may introduce evidence, but many statutes, both state and federal, provide that important administrative tribunals may place their own engineers, accountants, doctors or inspectors on the stand and have them present testimony under oath and subject to cross-examination. ${ }^{14}$

11 Cal. Stats. 1917 , c. $586, \S 60(a)$, pp. 831,871 ; Continental Casualty Company v. Industrial Accident Commission (1925) 195 Cal. 533, 538-9, 234 Pac. 317.

12 Baltimore \& Ohio Railroad Company v. United States (1924) 264 U. S. 258, 263, 265, 44 Sup. Ct. Rep. 317; United States v. Abilene \& Southern Ry. Co. (1924) 265 U. S. 274, 286-90, 44 Sup. Ct. Rep. 565; Northern Pacific Railway Co. v. Department of Public Works of Washington (1925) 268 U. S. 39, 45, 45 Sup. Ct. Rep. 412; Carstens v. Pillsbury (1916) 172 Cal. 572, 577, 158 Pac. 218.

${ }_{13}$ Homan v. Board of Dental Examiners (1927) 74 Cal. Dec. 633, 636; Anderson v. Board of Dental Examiners (1915) 27 Cal. App. 336, 338-40, 149 Pac. 1006; Benton v. Industrial Accident Commission (1925) 74 Cal. App. 411, 414-15, 240 Pac. 1021; Rich v. McClure (1926) 50 C. A. D. 311, 248 Pac. 275; People v. Board of Excise (1896) 40 N. Y. S. 741, 17 Misc. Rep. 98: 23 C. J. 172.

14 This may be the case even where the tribunals exercise judicial functions. Marin Water and Power Company v. Railroad Commission (1916) 171 Cal. 706, 713-14, 154 Pac. 864, Ann. Cas. 1917c, 114; Pacific Gas and Electric Company v. Devlin (1922) 188 Cal. 33, 41, 203 Pac. 1058. 
Before these administrative tribunals, the Government itself is interested in the ascertainment of the truth.

Before such tribunals, the hearing is more than a mere contest between private litigants playing the game in accordance with established rules of court. It has become an inquiry in which the state or the nation itself has an interest in seeing that full justice is done and sufficient intelligence to arrange that disinterested testimony is presented.

It is hoped that the foregoing, necessarily somewhat general comments, will serve to invite attention to a practice and procedure which are destined to loom constantly larger in the experience of most members of the profession.

Max Thelen.

San Francisco, California. 